\title{
Water Quality Assessment of West Tarum Canal for Drinking Water Supply
}

\author{
Ayu Widya Utami $^{1}$, Dwi Nowo Martono ${ }^{1,}$, and Haruki Agustina ${ }^{1}$ \\ ${ }^{1}$ School of Environmental Science, Universitas Indonesia, Jakarta, 10430, Indonesia
}

\begin{abstract}
West Tarum Canal (WTC) is a canal that drains raw water from the Jatiluhur Dam. Nearly $81 \%$ of the raw water for drinking water used by Jakarta's people comes from this canal. However, various land uses such as agriculture, industry, settlements, and infrastructure development impact WTC's water quality. This research aims to assess WTC's water quality in 2016-2020 based on water quality standards set by the Government and using the STORET method. The results of this research indicate that the concentrations of TDS (142-351 mg/L), Fe (0.1-0.15 mg/L), Mn (0.03-0.1 $\mathrm{mg} / \mathrm{L})$ are meet the standards, while DO (3.6-4.9 mg/L), BOD (4-10 $\mathrm{mg} / \mathrm{L})$, COD $(13-30 \mathrm{mg} / \mathrm{L})$ are not meet the standards. Almost all monitoring points have $\mathrm{pH}$ values between 5.75-7.68 that are meet the standards. The STORET score of WTC is from -26 to -38 with an average of -30 , which indicates that WTC's water quality is moderately polluted. Water contamination in WTC will burden the drinking water processing and ultimately affect the community's ability to pay for drinking water. This research also shows the need for integrated management of WTC from upstream to downstream and the need to increase collaboration between stakeholders in carrying out this management.
\end{abstract}

\section{Introduction}

Access to safe drinking water is a human right and is a fundamental necessity for humans to live. However, more than two billion people in the world do not have access to safe drinking water [1]. It is predicted that by 2025 , about 1.8 billion people will experience water scarcity, and two-thirds of the world's population will face a lack of clean water [2]. World water consumption is expected to double by 2030 and exceeds the available water supply by more than $40 \%$ due to increased population growth and rapid economic growth [3].

Freshwater is the most widely used water resource for various kinds of human life needs, one of which is drinking water. Freshwater consists of groundwater and surface water (such as rivers, lakes, etc.) with a percentage of fresh water on earth around $2 \%$ [4]. Until now, groundwater is still the most widely used source of water to meet drinking water needs because it usually has better water quality than surface water $[5,6]$. However, in the

* Corresponding author: dwi.nowo11@ui.ac.id 
last few decades, increasing demand for water and groundwater overexploitation has made this resource unsustainable and led to land subsidence [7].

Surface water also has problems, namely related to susceptibility to water pollution. Many pollutants reach surface water through different sources, and water pollution has become a significant environmental issue worldwide [8]. Water pollution often occurs in surface water because of the important role it plays as a transportation route for the disposal of domestic and industrial wastes and runoff from agricultural land $[9,10]$. On the other hand, surface water is also one of the most widely used water resources to fulfil drinking water needs. Therefore, if surface water is contaminated, it will cause many people to have access to unsafe drinking water.

Almost all surface water around the world has experienced a decline in water quality, and since 1990 water pollution has worsened in most surface waters in Latin America, Africa, and Asia [11]. Until now, most of the surface water in Indonesia is in polluted conditions. That is, almost $59 \%$ of rivers in Indonesia are categorized as heavily polluted [12]. This water pollution causes many Indonesians to experience a shortage of clean and drinking water, with a total population of nearly 28 million people affected [13]. Water pollution that occurs in Indonesian rivers is dominated by anthropogenic activities such as domestic activities, agriculture, industries, etc [14-18].

The West Tarum Canal (WTC) is one of the surface waters used as a raw water for drinking water source for Jakarta people. Nearly $81 \%$ of the raw water for drinking water for Jakarta people comes from this canal [19]. With the percentage of use of WTC water, water pollution and a decrease in WTC's water quality will be a threat to the availability of drinking water supply for Jakarta people. They can also be burdensome for the drinking water treatment process that will be carried out. Besides, if the water quality of WTC worsens, it will cause an increase in water rates due to increasing production costs, which will then impact people's ability to pay for drinking water. Thus, water quality is one of the important points that can affect the supply of drinking water. Based on this, this research aimed to assess the water quality of the West Tarum Canal.

\section{Methods}

\subsection{Water quality monitoring points}

This research was conducted in the West Tarum Canal (WTC) which flows from Curug Dam, Karawang to Cawang, East Jakarta and has a length of approximately $\pm 68 \mathrm{~km}$. The selection of WTC water quality monitoring points in this research is based on the sampling points used by Perum Jasa Tirta II with ten sampling points which can be seen in Figure 1. 


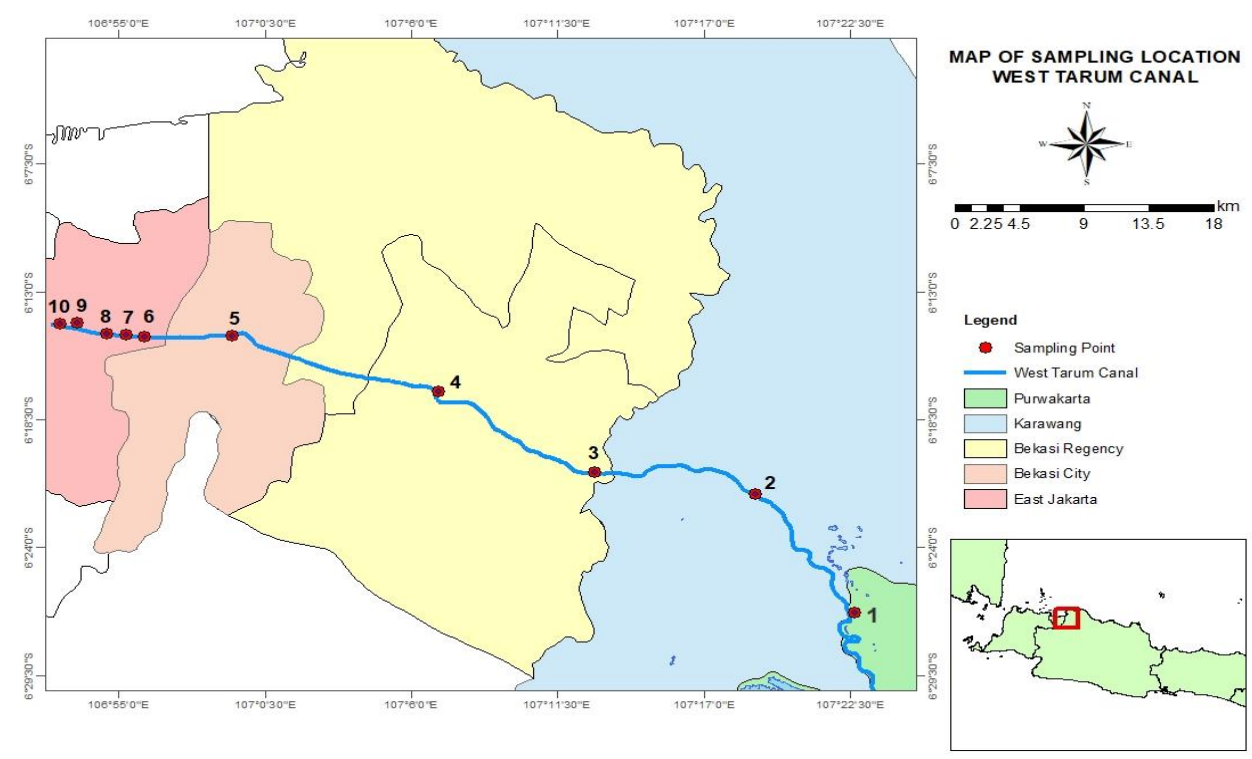

Fig. 1. Sampling points of West Tarum Canal

\subsection{Water quality assessment}

In this research, water quality data for the West Tarum Canal from 2016-2020 were obtained from Perum Jasa Tirta II with parameters in the form of Total Dissolved Solids (TDS), pH, Dissolved Oxygen (DO), Biochemical Oxygen Demand (BOD), Chemical Oxygen. Demand (COD), Iron (Fe), and Manganese (Mn). Water quality assessment of WTC is carried out by comparing water quality with class 1 of water quality standards (raw water for drinking water) based on Government Regulation No. 82 of 2001 concerning Water Quality Management and Water Pollution Control (see Table 1).

Then, the water quality assessment was also carried out using the STORET method. The STORET method is a method for determining water quality status by comparing water quality data with predetermined water quality standards. In assessing water quality status using the STORET method, the time series data of water quality are required. In the STORET method, if the water quality met the water quality standards, it can be given a score of 0 , whereas if the water quality exceeds the quality standards, it can be given a score according to the provisions in Table 2.

Table 1. Class 1 of water quality standard based on Government Regulation No. 82 of 2001

\begin{tabular}{|l|c|c|}
\hline \multicolumn{1}{|c|}{ Parameters } & Unit & Water Quality Standards \\
\hline Total Dissolved Solids (TDS) & $\mathrm{mg} / \mathrm{L}$ & 1000 \\
\hline $\mathrm{pH}$ & - & $6-9$ \\
\hline Dissolved Oxygen (DO) & $\mathrm{mg} / \mathrm{L}$ & $6^{*}$ \\
\hline Biochemical Oxygen Demand (BOD) & $\mathrm{mg} / \mathrm{L}$ & 2 \\
\hline
\end{tabular}




\begin{tabular}{|l|c|c|}
\hline \multicolumn{1}{|c|}{ Parameters } & Unit & Water Quality Standards \\
\hline Chemical Oxygen Demand (COD) & $\mathrm{mg} / \mathrm{L}$ & 10 \\
\hline Iron $(\mathrm{Fe})$ & $\mathrm{mg} / \mathrm{L}$ & 0.3 \\
\hline Manganese $(\mathrm{Mn})$ & $\mathrm{mg} / \mathrm{L}$ & 0.1 \\
\hline
\end{tabular}

Note: $(*)$ minimum standard

Table 2. STORET score system

\begin{tabular}{|c|c|c|c|c|}
\hline \multirow{2}{*}{$\begin{array}{c}\text { Number of } \\
\text { Parameters }\end{array}$} & \multirow{2}{*}{ Score } & \multicolumn{3}{|c|}{ Parameters } \\
\cline { 2 - 5 } & Physical & Chemical & Biological \\
\hline$<10$ & Minimum & -1 & -2 & -3 \\
\hline & Average & -3 & -2 & -3 \\
\hline & Maximum & -2 & -6 & -9 \\
\hline & Minimum & -2 & -4 & -6 \\
\hline & Average & -6 & -12 & -18 \\
\hline
\end{tabular}

After giving the score and adding the overall STORET score, then the water quality status classification is carried out, which provisions can be seen in Table 3.

Table 3. Water quality status

\begin{tabular}{|c|c|c|}
\hline Class & STORET Score & Water Quality Status \\
\hline A & 0 & Meet quality standards \\
\hline B & -1 to -10 & Slightly polluted \\
\hline C & -11 to -30 & Moderately polluted \\
\hline D & $\geq 31$ & Heavily polluted \\
\hline
\end{tabular}

\section{Results and Discussion}

The West Tarum Canal (WTC) is a canal that drains raw water from the Jatiluhur Dam. WTC has a length of about $68 \mathrm{~km}$ that crosses two districts (Karawang Regency and Bekasi Regency) and two cities (Bekasi City and Jakarta City). WTC began operating in 1968 and has three important roles: generating electricity, irrigating irrigation, and as a source of raw water for drinking [20,21]. The water quality of WTC is an important factor in the 
provision of drinking water for Jakarta people because approximately $81 \%$ of Jakarta's raw water sources for drinking water come from this canal.

The quality of raw water is an important indicator in the drinking water treatment process because it will affect the quality of drinking water produced [22]. If the raw water is of good quality, the drinking water treatment process will be lighter [23]. Changes in raw water quality will have an impact on changes in drinking water treatment production costs $[24,25]$. Water quality parameters that the performance of raw water treatment into drinking water include TDS, BOD, COD, Iron (Fe), and Manganese (Mn) [26]. In addition, pH and DO are also essential parameters in drinking water treatment and are commonly used to measure the water condition. The water quality of WTC during 2016-2020 can be seen in Figure 2.

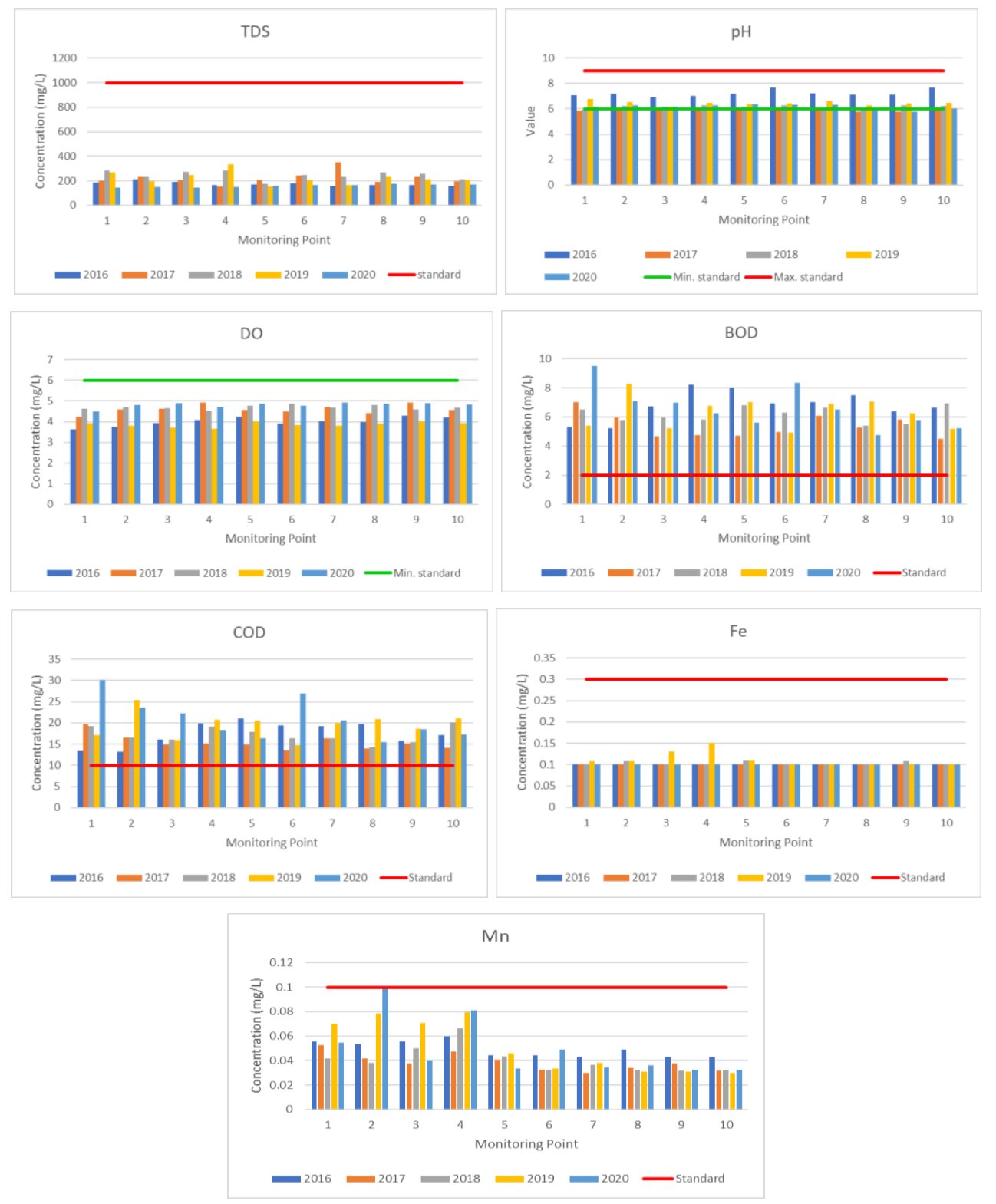

Fig. 2. Water quality of West Tarum Canal 2016-2020 
The factors affecting water quality are complex [27]. Water quality depends on climatic conditions, geographic location, site-specific conditions, human activities and the presence of pollution sources [28]. Based on Figure 2, the water quality of WTC during 2016-2020 has fluctuated. Of the seven water quality parameters, three parameters still meet class 1 of water quality standards based on Government Regulation No. 82 of 2001, such as TDS, Fe, and $\mathrm{Mn}$. TDS concentration ranges between $142-351 \mathrm{mg} / \mathrm{L}$, which indicates that the TDS concentration is still meeting the water quality standards.

The highest average of TDS concentration was at monitoring point 4 (concentration: $217 \mathrm{mg} / \mathrm{L}$ ). This is due to the input from other surface water with a high TDS concentration. At that point, there are several illegal settlements, small and medium enterprises or small industries that contribute to increasing the TDS concentration in WTC. The main sources of TDS in water can come from agricultural run-off, domestic waste, and industry [29]. Suppose the TDS concentration in water is too high. In that case, it will interfere with the survival and biological productivity of aquatic organisms and cause several health problems in humans, including eye and skin irritation [30].

$\mathrm{Fe}$ and $\mathrm{Mn}$ are naturally contained in water but at relatively small concentrations. High concentrations of $\mathrm{Fe}$ and $\mathrm{Mn}$ in water are usually caused by anthropogenic activities around water bodies[31,32]. The concentrations of Fe and Mn in the WTC ranged from 0.1$0.15 \mathrm{mg} / \mathrm{L}$ and $0.03-0.1 \mathrm{mg} / \mathrm{L}$, respectively. Fe and Mn's highest concentrations are in the WTC upstream between monitoring points 2 to 4 , while the downstream tends to be smaller. This is because in the upstream, there are still many activities to dispose domestic waste, both liquid and solid waste, which are disposed directly into water bodies. The increase in Fe and Mn metals in water which are used as a source of raw water for drinking water will cause problems, such as corrosion of pipes and accumulation of sediment in drinking water distribution systems [33,34].

Changes in $\mathrm{pH}$ values result from spatial and temporal variations in environmental conditions such as human activity, aquatic organisms, and climatic conditions [35]. The $\mathrm{pH}$ value at almost all monitoring points has a value in accordance with the quality standards with a range between 5.75-7.68. Very acidic water can corrode pipes, while very alkaline water is usually bitter and can cause a build-up of sediment in the pipes [36]. A very low $\mathrm{pH}$ causes metals' solubility in the water to increase, which is toxic to aquatic organisms. On the other hand, high $\mathrm{pH}$ can increase the concentration of ammonia in water which is also toxic to aquatic organisms [37].

Then, three water quality parameters do not match quality standards, namely Dissolved Oxygen (DO) with a range of 3.6-4.9 mg/L, Biochemical Oxygen Demand (BOD) with a range of 4-10 mg/L, and Chemical Oxygen Demand (COD) with a range of 13-30 $\mathrm{mg} / \mathrm{L}$. Increasing BOD and COD will reduce DO concentrations in the water. DO acts as an essential indicator of water quality used to assess water health, while BOD and COD are considered indicators of pollution in water [38,39]. Domestic and urban activities caused the high concentrations of BOD and COD in the WTC. Also, inflows from other surface water contributed to increased BOD and COD concentrations in the WTC. The high BOD and COD in WTC indicates that organic materials have polluted WTC water. The presence of organic matter will cause odor, taste, color and interfere with the drinking water treatment process [40].

Water quality is an important indicator to determine the potential use of water and is one of the most important factors contributing to human health [28,41]. Currently, various water quality assessment methods have been developed to support water quality management, such as water quality index, pollution index, fuzzy comprehensive evaluation, multivariate analysis, and others $[42,43]$. Assessment of the water quality can also be done using the STORET method. Based on STORET calculations, WTC's water quality ranges 
from -26 to -38 (see Figure 3) with an average of -30 , which indicates that the water quality of WTC has been moderately polluted.

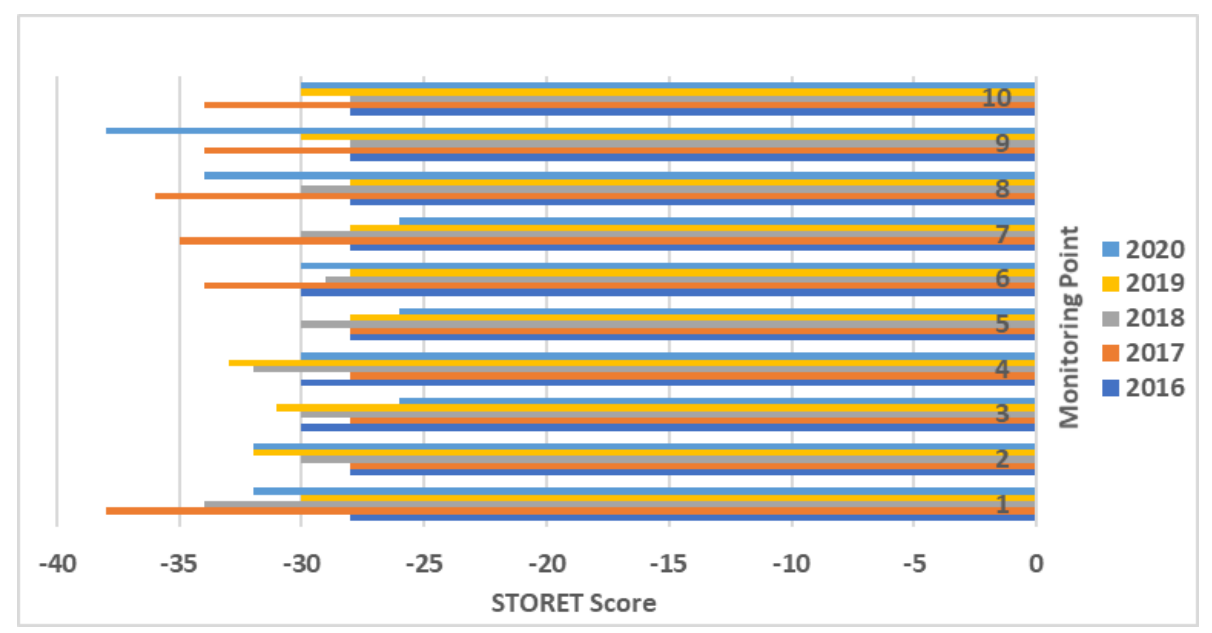

Fig. 3. STORET Score of West Tarum Canal 2016-2020

The primary source of pollution in surface water arises from anthropogenic activities, mainly due to the people's unhygienic living habits and environmentally unfriendly activities from agriculture and industries that dispose of their waste without being processed first [44]. Anthropogenic activities dominate the source of water pollution in WTC. In the upstream of WTC, many illegal settlements do not have private washrooms in their houses, so bathing and washing activities are carried out directly in the WTC's water bodies. In addition, run-off from agriculture and solid waste in water bodies and around the upstream banks of the WTC also contribute to water pollution that occurs.

In the middle stream of WTC, the source of pollution is not only dominated by settlements and agriculture. However, it is also caused by small and medium enterprises or small industries around the banks of the canal, which dispose of liquid or solid waste directly into water bodies. In addition, the entry and mixing of other surface water, namely the Cikarang River, which has poor water quality, cause the decline of water quality of WTC and it becomes polluted. Meanwhile, the downstream of WTC, infrastructure development activities around the canal contribute to water pollution.

Water pollution that occurs at raw water sources will limit or stop the water intake at the intake for drinking water production due to the poor quality of the raw water [45]. Water pollution that occurs in the WTC will be burdensome to the drinking water treatment process and impact increasing the cost of water treatment production. One of the reasons for this increase in production costs was the addition of doses and types of chemicals so that the processed water conforms to drinking water quality standards. The cost of using chemicals made a significant contribution to the cost of drinking water treatment, with a percentage of $15.5 \%$ [46]. On the other hand, an increase in production costs will impact determining the water tariff that will be offered to the community, which will later impact the community's ability to pay for drinking water.

Based on this, it is important to carry out water management for the West Tarum Canal to meet the predetermined raw water for drinking water quality standards. Good quality of raw water will ease the water treatment process and increase the quantity and continuity of the community's drinking water supply. WTC's water management must be carried out in an integrated manner from upstream to downstream, bearing in mind that the upstream conditions will influence the downstream conditions. Surface water management 
cannot be handled in isolation. It is necessary to consider ecosystems' functioning simultaneously at different hierarchical levels, both in space and time [47]. On the other hand, to achieve success in WTC's water management, it is necessary to increase collaboration between stakeholders, from the community to the Government.

\section{Conclusion}

The parameters of TDS, Fe, and Mn in the West Tarum Canal (WTC) are still meeting the class 1 of water quality standards based on Republic of Indonesia Government Regulations No. 82 of 2001, while DO, BOD, and COD were not in accordance with the standards. At almost all monitoring points, the $\mathrm{pH}$ value met the standards. Based on the STORET method, WTC's water quality has been moderately polluted with an average STORET score of -30. As a source of raw water for drinking water, water contamination in WTC will aggravate the drinking water treatment process that will be carried out and can increase drinking water tariff due to increased water treatment production costs. Increasing the drinking water tariff will have an impact on people's ability to pay for drinking water. Therefore, WTC's integrated management is needed from upstream to downstream, and it is necessary to increase collaboration between stakeholders in carrying out this management.

\section{References}

1. C. He, C. P. Harden, and Y. Liu, Geogr. Sustain. 1, 98 (2020)

2. Y. ping Chen, B. jie Fu, Y. Zhao, K. bo Wang, M. M. Zhao, J. fu Ma, J. H. Wu, C. Xu, W. gang Liu, and H. Wang, J. Clean. Prod. 263, (2020)

3. T. Hashimoto, P. A. Gunawan, S. Wattanachira, A. Wongrueng, and S. Takizawa, Water (Switzerland) 11, 1 (2019)

4. M. S. Zaman and R. C. Sizemore, J. Mississippi Acad. Sci. 62, 348 (2017)

5. J. Van Engelenburg, E. Van Slobbe, and P. Hellegers, J. Integr. Environ. Sci. 16, 89 (2019)

6. S. Amira, T. E. B. Soesilo, and S. S. Moersidik, in IOP Conf. Ser. Earth Environ. Sci. (2019), pp. 1-8

7. A. Abrishamchi, F. Khakbazan Fard, and A. Taghavi, Agric. Water Manag. 229, 105835 (2020)

8. E. M. Brovini, B. C. T. de Deus, J. A. Vilas-Boas, G. R. Quadra, L. Carvalho, R. F. Mendonça, R. de O. Pereira, and S. J. Cardoso, Sci. Total Environ. 771, (2021)

9. O. Daniel, N. L. Ify, M. O. L. Yusuf, and N. B. Onyedikachukwu, J. Eng. Res. Reports 12, 18 (2020)

10. A. Ghadouani and L. X. Coggins, Phys. Chem. Earth 36, 335 (2011)

11. S. Yadav, M. S. Babel, S. Shrestha, and P. Deb, Environ. Monit. Assess. 191, (2019)

12. I. Sulthonuddin, D. M. Hartono, S. W. Utomo, and C. A. A. Said, in IOP Conf. Ser. Earth Environ. Sci. (2019)

13. Water.org, (2020)

14. T. Zubaidah, N. Karnaningroem, and A. Slamet, ARPN J. Eng. Appl. Sci. 13, 3692 (2018)

15. A. Hayati, N. Tiantono, M. F. Mirza, I. D. S. Putra, M. M. Abdizen, A. R. Seta, B. M. Solikha, M. H. Fu'adil, T. W. C. Putranto, M. Affandi, and Rosmanida, J. Biol. Res. 22, 43 (2017)

16. T. Akbari and F. S. P. Pangesti, in 1st Int. Multidiscip. Conf. Educ. Technol. Eng. (2020), pp. 131-134 
17. M. Cahyanto, B. Yusuf, and R. Kartika, 12, 73 (2019)

18. D. Ratnaningsih, E. L. Nasution, N. T. Wardhani, O. D. Pitalokasari, and R. Fauzi, in IOP Conf. Ser. Earth Environ. Sci. (2019)

19. PAM Jaya, Annual Report 2019 Expanding Services: Fulfilling Citizens's Right on Clean Water (Jakarta, 2019)

20. M. Sumiarsih, D. Legono, and R. Kodoatie, Eco Rekayasa 11, 35 (2015)

21. S. D. K. Dewi and W. Wardhana, in IOP Conf. Ser. Earth Environ. Sci. (2020), pp. $1-5$

22. H. Ren, R. Tröger, L. Ahrens, K. Wiberg, and D. Yin, Environ. Sci. Eur. 32, 1 (2020)

23. J. A. Palomero-González and F. Hernández-Sancho, Water Sci. Technol. Water Supply 18, 1357 (2018)

24. J. I. Price and M. T. Heberling, Ecol. Econ. 151, 195 (2018)

25. M. T. Heberling, C. T. Nietch, H. W. Thurston, M. Elovitz, K. H. Birkenhauer, S. Panguluri, B. Ramakrishnan, E. Heiser, T. Neyer, and 1Sustainable, Water Resour. Res. 5, 8741 (2015)

26. S. S. Moersidik and D. M. Hartono, Lingkung. Trop. 3, 23 (2009)

27. C. O'Donoghue, C. Buckley, A. Chyzheuskaya, S. Green, P. Howley, S. Hynes, V. Upton, and M. Ryan, Land Use Policy 103, (2021)

28. K. Haldar, K. Kujawa-Roeleveld, P. Dey, S. Bosu, D. K. Datta, and H. H. M. Rijnaarts, Sci. Total Environ. 708, 134559 (2020)

29. Rinawati, D. Hidayat, R. Suprianto, and P. Dewi, Anal. Environ. Chem. 1, 36 (2016)

30. M. Sakizadeh, J. Contam. Hydrol. 221, 26 (2019)

31. M. Bhaskar, A. K. Dixit, K. K. Ojha, S. Dubey, A. Singh, and A. Abhishek, Bioinformation 16, 332 (2020)

32. B. Liang, G. Han, M. Liu, X. Li, C. Song, Q. Zhang, and K. Yang, Water (Switzerland) 11, 1 (2019)

33. C. Alvarez-Bastida, V. Martínez-Miranda, M. Solache-Ríos, I. Linares-Hernández, A. Teutli-Sequeira, and G. Vázquez-Mejía, J. Environ. Chem. Eng. 6, 2119 (2018)

34. Z. Zhang, C. Xiao, O. Adeyeye, W. Yang, and X. Liang, Water (Switzerland) 12, (2020)

35. S. Al-Asadi, Int. J. Mar. Sci. 6, 1 (2016)

36. I. B. Rahardja, A. L. Siregar, and A. W. L. B. Sihotang, Teknologi 12, 20 (2020)

37. F. Tatangindatu, O. Kalesaran, and R. Rompas, Budid. Perair. Mei 1, 8 (2013)

38. P. Sharma and S. Gupta, Am. Int. J. Res. Formal, Appl. Nat. Sci. AIJRFANS 14 (2014)

39. X. Ji, X. Shang, R. A. Dahlgren, and M. Zhang, Environ. Sci. Pollut. Res. 24, 16062 (2017)

40. G. K. Khadse, P. M. Patni, and P. K. Labhasetwar, Sustain. Water Resour. Manag. 1, 157 (2015)

41. A. Azad, H. Karami, S. Farzin, S. F. Mousavi, and O. Kisi, Water Sci. Eng. 12, 45 (2019)

42. N. Hien Than, C. Dinh Ly, and P. Van Tat, J. Hydrol. 596, (2021)

43. Y. Liu, Y. Hu, Y. Hu, Y. Gao, and Z. Liu, J. Environ. Sci. (China) 104, 40 (2021)

44. A. A. Adesuyi, V. C. Nnodu, K. L. Njoku, and A. O. Jolaoso, Int. J. Geol. Agric. Environ. Sci. 3, 14 (2015)

45. E. Wolff and M. T. H. van Vliet, Sci. Total Environ. 778, (2021)

46. D. Kusumawardani, Maj. Ekon. 116 (2012)

47. S. K. Jain and V. P. Singh, in Dev. Water Sci. (2003), pp. 787-842 